\title{
Витоки формування уявлення про концепт у філософії Людвіга Вітгенштейна
}

\author{
The origins of the idea of concept \\ in the philosophy of Ludwig Wittgenstein \\ Yuliia KALIUZHNA/Юлія КАЛЮЖНА ${ }^{1}$ \\ National Pedagogical Dragomanov University (Ukraine)
}

\begin{abstract}
The article attempts to investigate the origins of the idea of concept in the philosophy of Ludwig Wittgenstein and attempts to apply the theoretical work of L. Wittgenstein in combination with literary and linguistic techniques and methods of analysis to consider concepts and their elements in literary works. The author revealed the possibility of embodying the multidimensional interaction of different conceptospheres in the work of fiction literature, and also revealed differences between the national and the author's concepts.

Keywords: concept, conceptosphere, picture of the world, inoculture, "language game", "natural language", author's concept, national concept

\section{Анотація}

У статті здійснено спробу дослідити витоки формування уявлення про концепт у філософії Людвіга Вітгенштейна та здійснено спроби застосувати теоретичні напрацювання Л.Вігенштейна у комплексі 3 літературознавчими та лінгвістичними прийомами та методами аналізу для розгляду концептів та їх елементів у літературних творах. Автором було виявлено у художньому творі можливості втілення багатовимірної взаємодії різних концептосфер, виявлено відмінності між національним та авторським концептом.
\end{abstract}

1 https://orcid.org/0000-0001-9019-1004

Національний педагогічний університет імені М.П. Драгоманова (Україна)

National Pedagogical Dragomanov University (Ukraine), Faculty of Foreign Philology

juliekaliuzhna@gmail.com 
Ключові слова: концепт, концептосфера, картина світу, інокультура, «мовна гра», «природна мова», авторський концепт, національний концепт

\section{1. Вступ}

Сучасний світ диктує неймовірні темпи змін, перетворень та розвитку, на сьогоднішній день чи не кожен науковець говорить про глобалізацію та культурну уніфікацію, як результат глобалізаційних метаморфоз. На жаль, зміни - це не лише можливості, але й загрози. Сьогодні, як ніколи раніше, важливими є збереження національної своєрідності кожного етносу, його неповторного бачення світу у всіх його відтінках, гранях та складностях. Якщо розглядати мову як інструмент для передачі наявної інформації про світ, то важливо розуміти, що саме концепт буде ключовим елементом у цьому процесі, адже саме концепт $є$ продуктом мисленнєвої, ментальної діяльності, яка трансформується у слово i забезпечує глобальний обмін досвідом та знаннями не лише між поколіннями, але й між народами, націями, етносами.

Актуальність дослідження полягає у необхідності здійснення аналізу та експлікації витоків формування уявлення про концепт у філософії Людвіга Вітгенштейна.

Об'єктом дослідження $є$ концепт як одиниця.

Предмет аналізу становить поняття концепту у філософії Людвіга Вітгенштейна.

Варто зазначити, що дослідження концепту у філософії Людвіга Вітгенштейна було розглянуто у роботах вітчизняних та зарубіжних науковців. Лінгвісти (О.Селіванова, М.Манакін, А.Огар, А.Вежбицька), культурологи (Е.Хірш, В.Жайворонок), літературознавці (Ж. Клименко, Г.Токмань, Бахтін М.) відзначають роботи Вітгенштейна, як основу для дослідження концептів в контексті національного та полікультурного розвитку.

Метою роботи є визначення специфіки формування уявлення про концепт у філософії Людвіга Вітгенштейна та дослідження особливостей функціонування концептів у літературних творах.

Поставлена мета передбачає розв'язання таких завдань:

1) простежити розвиток формування уявлення про концепт у працях Л.Вітгенштейна; 
2) порівняти сучасні визначення терміну «концепт» у філософських працях Л.Вітгенштейна та в наукових роботах українських вчених;

3) простежити актуальність та доцільність використання теоретичних та практичних напрацювань Л. Вітгенштейна при дослідженні концептів у літературних творах;

4) дослідити концепт як імпліцитний компонент інокультурної та національної специфіки картини світу;

5) розглянути «природну мову» як можливість вирішення проблеми відчуження інокультури та безеквівалентної лексики;

6) виявити у художньому творі можливості втілення багатовимірної взаємодії різних концептосфер;

7) простежити взаємозв'язок та виявити відмінності в авторських та національних концептах;

8) здійснити спробу застосування теоретичних напрацювань Л.Вігенштейна у комплексі з літературознавчими та лінгвістичними прийомами та методами аналізу для розгляду концептів та їx елементів у літературних творах.

\section{Методи дослідження:}

теоретичні: систематизація досліджуваної проблеми на основі осмислення першоджерел, критичний аналіз; емпіричні: порівняння, узагальнення, аналіз результатів діяльності.

Теоретико-методологічна база дослідження включає в себе:

- філософські праці Людвіга Вітгенштейна;

- лекції та коментарі Сокулера 3.А. до філософських робіт Людвіга Вітгенштейна;

- роботи сучасних українських та зарубіжних лінгвістів та культурологів Селіванової О., Манакіна М., Огар А., Голубовської I при дослідженні визначення концепту;

- роботи методистів та літературознавців Сафаяна М, Клименко Ж.В., Токмань Г., Вежбицької А. Чижової Л.А;

- модель формування іміджу Ю.Запорожченка;

- модель «культурної грамотності» Е.Хірша-молодшого. 


\section{2. Теоретичні засади формування уявлення про концепт}

\section{1. Основні положення «Логіко-філософського трактату»}

\section{Л.Вітгенштейна та дві моделі мови}

Людвіг Вітгенштейн був представником аналітичної філософії, саме від був одним з перших філософів, які займались логічним аналізом мови. В центрі його філософських поглядів лежить ідея невідповідності мисленнєвих образів та денотатів. На думку Вітенштейна, основна проблема порозуміння полягає у невідповідності імен та елементів реального світу. Вчений вважав, що мова і світ $є$ ізоморфними елементами, що в мові можливо виділити схему співвідношення компонентів мовного мислення та елементів реального світу. Таким чином, філософ висловлює думку, що імена не мають сенсу, адже всього лише називають предмет, а головну роль в мовленнєвій діяльності відіграють речення, адже в них можна прослідковувати логіку побудови, а значить, i подібність функціонування мови і світу. Разом з тим Вітгенштейн піднімає питання обтяжливості багатозначності слів, що присутня у природній мові. Така багатозначність, на його думку, занадто ускладнює розуміння і призводить до «безсенсовості речень».

Як бачимо, Вітгенштейн виділяє два типи мови: природну неідеальну, переобтяжену множинами значень, та ідеальну мову науки, яку й описує у своєму «Логіко-філософському трактаті». Вчений пропонує наступну схему функціонування ідеальної мови науки:

- базовими елементами мови $\epsilon$ імена, які безпосередньо відповідають конкретним елементам реальності;

- базові елементи можуть створювати найпростіші логічні комбінації і тоді вони стають атомарними реченнями;

- 3 атомарних речень можуть бути складені більш складні структури - молекулярні речення, які теж мають будуватись за особливою логічною граматикою;

- саме логічний синтаксис повинен бути основою граматики ідеальної мови науки.

Вітгенштейн вважав, що подібна мова дозволить очистити науку від зайвих та обтяжливих висловлювань, зробивши іiі простою, логічною, а саме така мова і $є$ відображенням механізмів мислення. Таким чином, у ранніх поглядах філософа домінантною $є$ думка про можливість і навіть необхідність обмежити слово одним значенням. Так філософ підводить нас до думки, що світ - це не об'єкти, а факти, які й будуть описуватись 
атомарними та молекулярними реченнями. Підсумовує філософ свій «Логіко-філософський трактат» всім відомим афоризмом: «Про що не можна говорити, про те слід мовчати». Але таким чином «те, про що не можна говорити», а в цю категорію увійшли естетика, етика, метафізичні вчення, фактично виключається з кола наукового розгляду. Також слід зазначити, що від ідеальної наукової мови відходять певні настрої статичності мови, але ж саме полісемія $є$ однією з ознак мовного розвитку та відображенням етнокультурних особливостей (Бахтин, 1989).

Розуміння помилковості своїх суджень та усвідомлення неможливості та невиправданості створення ідеальної мови, підштовхують Вітгенштейна до необхідності виявлення і аналізу концептів, які не відображають елементи реального світу, а навпаки - визначають моделі поведінки людини у світі та відображають організацію процесу пізнання людиною світу, а саме людина, яка використовує мову, може вважатись функціональною осново процесу пізнання. Отже можемо сказати, що фокус уваги філософа змістився з опису фактів дійсності на специфіку усвідомлення, розуміння, відчуття та наміру людини, як творця природньої мови.

\section{2. «Філософські дослідження» та «мовні ігри» як ключ до розуміння поліфонії значень}

Переконавшись у неспроможності ідеальної мови науки звести всі варіації людської мови та всю множинність смислів слова до єдиного, Л.Вітгенштейн звертається до природної мови. Ідеї його досліджень були посмертно видані у праці «Філософські дослідження», в ній автор приділяє увагу опису мови та мовленнєвої поведінки. Саме в цій роботі мова розглядається як діяльність, що органічно поєднується з іншими видами діяльності. Мова має за мету досягнення конкретних цілей у конкретних умовах, тут проглядається прагматичний аспект мови. Мова використовується у всіх множинах ситуацій, у яких може опинитись людина. Тут Л.Вітгенштейн вводить поняття «мовної гри», складовими якої $є$ два аспекти - вживання виразу і розуміння виразу. Вживання виразу філософ називає «ходом» у мовній грі, а кожна гра до того ж має особливі правила, які мають значення лише в рамках окремо взятої гри. Поруч 3 мовними іграми автор розглядає «гру поведінки». Така гра $є$ моделлю соціальної поведінки, що закріплена традиціями і головною з таких ігор поведінки філософ вважає мову. Змінюються докорінно і погляди Л.Вітгенштейна на причини труднощів «безсенсовості речень»: якщо 
у «Логіко-філософському трактаті» причиною була множинність трактувань значення слова, то тепер в причиною філософ називає саме неврахування усіх специфічних значень слова та змішування правил різних мовних ігор.

Певною мірою концептуальна картина світу, про яку йшла мова вище, $є$ варіацією мовної гри. Адже, часто непорозуміння та відчуження інокультури обумовлені розбіжностями у колективних та індивідуальних концептосферах. На думку Л.Вітгенштейна, зміст концепту можна описати за допомогою парадигми вживання слова, що його (концепт) позначає. 3 цього виходить, що неможливим $\epsilon$ пояснення концепту через знаходження його конкретних чи абстрактних квінтесенцій [Бахтин 1979]. Це можна зробити лише звертаючись до варіацій вживання слова, що його позначає. При цьому правила мовної гри, за якими варіації вживання слова $\epsilon$ можливими, слід визначати зі загальноприйнятої поведінки людей, що $\epsilon$ типовою у суспільстві. Більше того, таку поведінку філософ називає «референтною системою», яка допомагає нам інтерпретувати незнайому мову.

\section{3. Наукове обгрунтування концепту в роботах Л.Вітгенштейна та сучасних вітчизняних літературознавців, культурологів та лінгвістів} У своїй останній праці Л.Вітгенштейн розглядає мову як важливий елемент людської діяльності та вказує, що концепти виражаються у парадигмах вживання слів і на них будується концептуальна картина світу.

Таким чином концептосферу ми можемо розглядати як особливу систему інформації про світ, що $є$ уявленням людини про оточуючу об’єктивну дійсність. Значна роль у побудові концептосфер належить природній мові. У своїй статті Чижова Л. (Чижова, 2007) вважає, таке співвіднесення мови 3 навколишнім світом $\epsilon$ кодуванням мовними засобами певних фрагментів концептуальної системи. Прикріпленість виразів мови як знакової системи до певних фрагментів концептуальної системи дозволяє оперувати складовими концептосфери. Соціальна взаємодія між людьми призводить до побудови та адаптації системою такої інформації, яка не може бути сконструйована без мови i яка дає можливість вийти за межі безпосереднього досвіду конкретного окремої людини. При цьому будь-яка нова інформація, отримана в результаті розвитку суспільства, стає частиною видозміненої концептуальної системи. 
Постійна участь в «мовних іграх», що обумовлені існуванням людини в рамках певних соціальних взаємозв'язків, і обумовлює створення концептів: відсутність концептів та концептосфери у свідомості людини веде до неадекватного відображення фактів дійсності, та до неможливості орієнтуватись у світі та пізнавати його. Далі Л.А. Чижова (Чижова, 2007) вказує, що вихідним етапом формування концепту $є$ особливий момент, коли органи чуття, мозок та нервова система у симбіозі з об'єктом навколишньої дійсності формують у свідомості суб'єктивний образ об'єктивної дійсності. Таким чином на етапі початкового пізнання об'єкта дійсності у свідомості людини він відображається з базовими і найбільш необхідними в даний момент часу характеристиками, поступово обростаючи смислами та перетворюючись у концепт.

Схожу модель концепту подає у своїх працях український лінгвіст Селіванова О. [Селіванова 2012, ] Ї̈̈ модель концепту також передбачає внутрішнє ядро, навколо якого розташована периферія (несуперечлива інформація), за периферією - модус, який включає в себе смисли, які концепт вбирає поступово, включаючи оцінно-емотивний компонент. Такий компонент дозволяє нашаровувати асоціативні та метафоричні смисли.

Розглядаючи обгрунтування концепту у роботах науковців, слід всебічно розглянути поняття картини світу. Манакін В.М. розглядає картину світу як «ментальне уявлення про світ, його інтелектуальну копію, що формується за законами діяльності людської свідомості і має різні форми існування залежно від форм пізнання дійсності (Манакін, 2012). При цьому під словом «світ» вчений розглядає не лише наочну навколишню дійсність, але i людську розумову інтерпретацію такої дійсності.

Слідом за цим розглядають i мовну картину світу, що $\epsilon$ відображенням у категоріях і формах мови уявлення певної національної спільноти про дійсність. Втім, мовна картина світу не може бути втіленою без концептуальної картини світу, що $є$ системою концептів як значущих психоментальних координат, за якими визначають межі національної свідомості, концептосфери нації. Концептуальна картина світу $\epsilon$ надзвичайно багатою, адже окрім мовних засобів втілення, вона використовує невербальні засоби висловлювання, емоційні засоби, асоціації, культурні ознаки. 
Таким чином, концепти формують концептосфери, які знаходять своє відображення у мовній та концептуальній картинах світу. При цьому в мовній - відображаються як знаковий елемент, у концептуальній - як ментально-образна проекція суб'єкту дійсності. Дана взаємодія подана у Схемі 1.1.

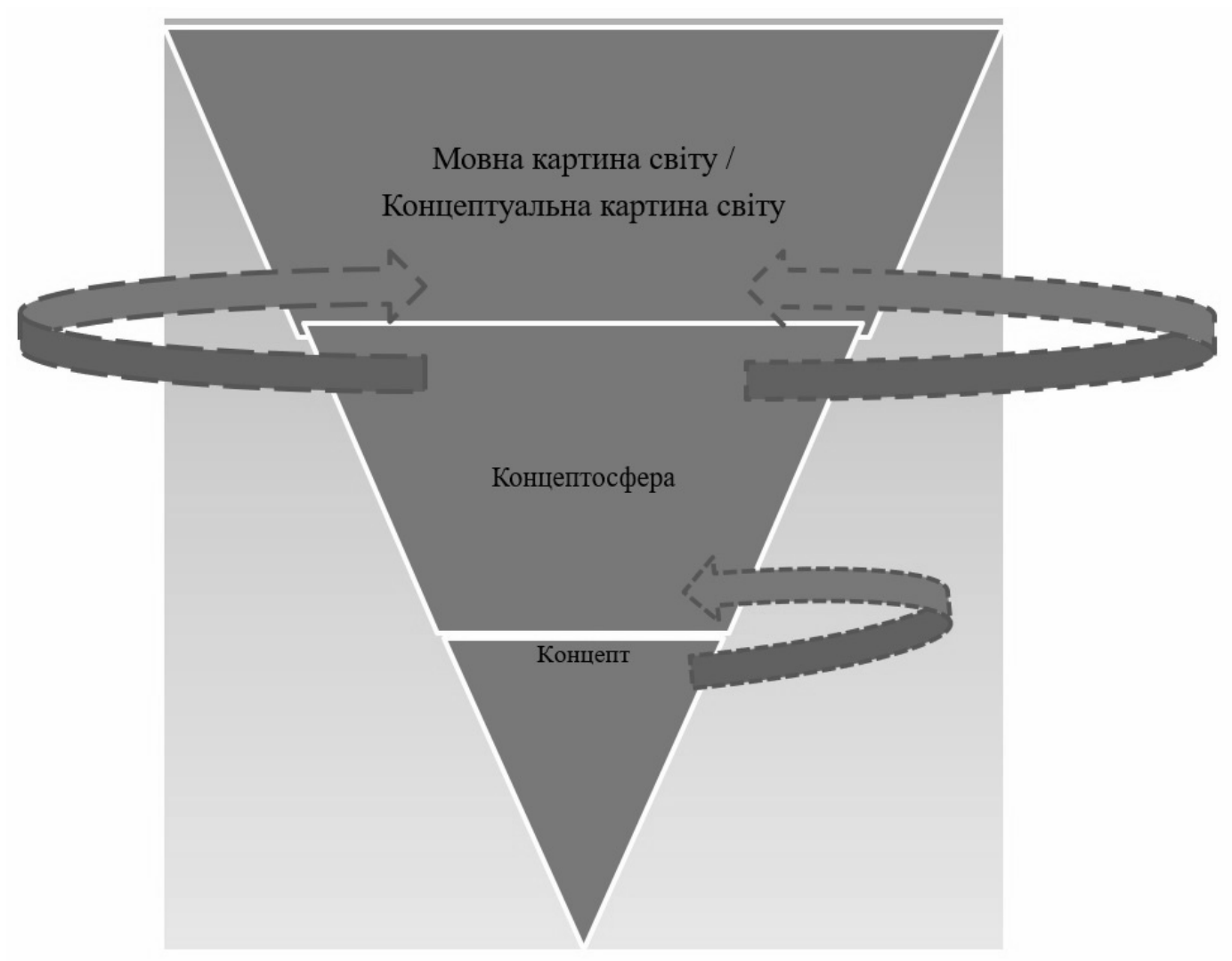

Схема 1.1

Аналізуючи розуміння концепту в роботах Л.Вітгенштейна, Чижова Л.А. пише, що вивчення функції мови як засобу, інструменту членування і осмислення навколишньої дійсності в аналітичній філософії послужило основою формування уявлення про систему культурно обумовлених концептів, які втілені в природній мові, що обслуговує процес комунікації (Чижова, 2007). Засвоєння як конкретними людьми, так і певними поколіннями людей вже існуючих концептів, вживання відповідних їм мовних виразів означають використання результатів практичного досвіду соціуму, нації. 
У контексті культури пропонує розглядати концепт В.Жайворонок: «мовна одиниця функціонує не як слово-номінація, а як слово-концепт, вмістилище певного сенсу, що дає підстави вважати слово культурним концептом.» (Жайворонок, 2006) Ще одне цікаве визначення дає I. Голубовська (Огар, 2013), яка розглядає концепт, як комплекс культурно детермінованих уявлень про предмет.

Таким чином, ми можемо говорити про актуальність теоретичних напрацювань Людвіга Вітгенштейна, адже запропонована модель концепту та концептосфери залишається актуальною сьогодні і структура концепту, запропонована науковцями часто складається з подібних елементів.

\section{3. Практичне втілення ідей Л. Вітгенштейна у сучасній лінгвістиці та літературознавстві}

\section{1. Концепт як імпліцитний компонент інокультурної та національної специфіки картини світу}

Велике значення для осягнення розглядуваної проблеми мають лінгвокультурологічний та країнознавчий аспекти. Доктор педагогічних наук, професор Клименко Ж.В. в монографії «Теорія і технологія вивчення перекладних художніх творів у старших класах загальноосвітньої школи» (Клименко, 2006, с. 63-90), аналізуючи праці багатьох науковців, доводить, що знайомство з інокультурним твором, як і знайомство 3 представником іншої національності, має свої труднощі.

Вчена відзначає, що часто знайомство інокультурним твором, в якому представлена інша концептуальна картина світу, спричинює стан культурного шоку $[8,64]$, як реакцію на «прояви інокультурності», тобто несумісність двох культурних кодів - рідного та інокультурного. Зазначається, що культурний шок може мати як позитивне, так і негативне значення.

Аналіз багаточисленних робіт етнопсихологів, психологів, культурологів та літературознавців дав вченій можливість виділити наступні групи елементів (Клименко, 2006, с. 68-71), які сприймаються порізному представниками різних національностей. Всі ці елементи можна розглядати як складові концептосфери:

1. Національно-культурні символи - знаки, у яких первісний зміст виступає формою для вторинного. Наприклад, образ-символ журавлів у повісті Ясунарі Кавабата «Тисяча журавлів»: для слов'янських народів журавель є посланцем Господа. Вірили, що восени журавлі відносять на 
небеса душі померлих, а навесні - приносять душі немовлят, які мають народитись. Тобто журавель виконував функцію провідника душ. В Японії журавель - символ здоров'я, довголіття й щастя (Wierzbicka, 1997, с. 125). Незнання точного значення того чи іншого елемента веде до неправильного трактування усього твору, важливо дати правильну настанову, спрямувати на пошук інформації.

2. Національні еталони і стереотипи.

3. Національно-прецедентні феномени (відомі будь-якому середньому представнику тієї чи іншої національно-лінгво-культурної спільноти й такі, що входять у національну когнітивну базу). Наприклад, «Каменярів» одразу ідентифікують як твір Івана Франка, «Кайдашеву сім'ю» - Івана НечуяЛевицького.

4. Фрейм-структури свідомості як когнітивні одиниці, які прогнозують можливі асоціації. Прикладом можуть слугувати такі фреймструктури свідомості в українців:

Таблиця 2.1

\begin{tabular}{|l|l|}
\hline Кобзар & Тарас Шевченко \\
\hline Наталка & -Полтавка \\
\hline Кінь & вороний \\
\hline Козак & бравий \\
\hline
\end{tabular}

Подібні фрейм-структури $є$ результатом тривалого формування й карбування в свідомості нації певних образів, стереотипів, норм. Звісно, для кожної нації вони індивідуальні, адже кожна проходить свій шлях.

Розглядаючи концепт БЕЗСМЕРТЯ в українській, французькій та англійській мовах, було помічено, що герої, які володіють безсмертям у творах українських письменників - $\epsilon$ представниками світлих сил: ельфи, мавки, дріади, духи; тоді як в англомовній та франкомовній художній літературі переважно безсмертними $\epsilon$ вовкулаки, вампіри, перевертні. Концепт БЕЗСМЕРТЯ закарбований у свідомості представників етносу у комплексі з концептом ЗЛО (EVIL).

\section{2. «Природна мова» як можливість вирішення проблеми} відчуження інокультури та безеквівалентної лексики У лінгвістиці $є$ ряд питань, що прямо та/або опосередковано пов'язані 3 теорією Людвіга Вітгенштейна. Окрему книгу, присвячену питанню неперекладної та без еквівалентної лексики, написала А Вежбицька 
(Wierzbicka, 1997). Вчена аналізує різні мови і приходить до висновку, що існує особлива безеквівалентна лексика, яка являє собою особливі лексичні одиниці, що не можуть бути перекладені з однієї мови на іншу в силу відсутності аналогічного, еквівалентного слова та поняття в одній 3 мов. Наприклад, у повісті Я.Кавабати «Тисяча журавлів» зустрічається слово «обі». Обі - це пояс для кімоно, його можна вважати абсолютним елементом японської концептуальної картини світу, адже так само як і кімоно - обі $є$ традиційним, ментально закріпленим образом у свідомості носіїв культури.

I тут постає проблема неможливості подачі точного переклалу, оскільки це буде певною мірою порушення правил «мови гри», що в результаті веде до втрати національної своєрідності твору. Тому природна мова і гра поведінки відіграють роль у розумінні сутності речі. Таким чином перекладачі подають варіант «пояс для кімоно» у примітках, а в самому ж художньому перекладі лишається національно-специфічне слово «обі». У ході дослідження значну вагу надавали і компаративному аспекту.

Оскільки ми говоримо про інокультурний художній твір, варто звернути увагу на можливість порівняння двох культур, творів, образів... Черкезова М. в монографії «Русская литература в национальной школе» пише про принципи спільності та національної своєрідності, які обов'язково мають реалізуватись при вивченні літератури (Черкезова, 1981, с. 93-94). Це дає можливість не лише поглибити знання про інокультуру, але й сприяти зацікавленню рідною.

Компаративний аспект може реалізовуватись шляхом порівняння етнокультурних елементів двох країн. Наприклад, таку табличку склали учні при вивченні повісті «Тисяча журавлів» Ясунарі Кавабата:

Таблиця 2.2

\begin{tabular}{|l|l|}
\hline Кімоно & Вишиванка \\
\hline Бамбук & Верба \\
\hline Гора Фудзі & Говерла, Карпати \\
\hline Катана & Шабля \\
\hline Нецке & Писанка \\
\hline Сакура & Калина \\
\hline
\end{tabular}

Таке порівняння дає змогу зрозуміти, що є національним символом тієї чи іншої країни, чому вони так цінуються. 
Подані вище елементи $є$ концептами у свідомості носіїв культур, таким чином, кожен з них дає можливості створення, образів, символів, асоціативного ряду, а це відображає не лише концептуальну, але й ціннісну картину світу. Таке порівняння дає змогу зрозуміти, що $\epsilon$ національним символом тієї чи іншої країни, чому вони так цінуються.

\section{3. Художній твір як можливість втілення багатовимірної взаємодії різних концептосфер}

Говорячи про ізоморфні концепти як концепти, що відображаються один елемент дійсності у свідомості різних представників етнічної групи, ми маємо враховувати наявність так званих «фонових знань». Сафарян С.I. визначає фонові знання як «поза текстові знання, без яких неможливо до авторського задуму сприйняти художній твір» (Сафарян, 2003, с. 43-44).

Американський культуролог Е. Хірш-молодший (David S. Kaufer, 1981) у своїх численних роботах звертається до поняття «культурна грамотність». Під культурною грамотністю розуміється умовний список творів мистецтва та художніх явищ, а також життєвих реалій, які $\epsilon$ зрозумілими та актуальними для представників певної епохи чи покоління. Культурна грамотність - це постійно змінний феномен, список складових якого завжди носить описовий, а не обов'язковий характер. 3 часом одна течія в мистецтві змінюе іншу, змінюються і вподобання епохи, а також її культурно-естетичне наповнення. Мова йде не лише про твори високого мистецтва, а й про повсякденні масові розваги. Але якщо поява чи зникнення нового телевізійного шоу не заважає нам розуміти попередні епохи, то для розуміння їх глибинних настроїв, які сприяли формуванню того чи іншого концепту, треба додаткові знання. Це варто враховувати в першу чергу тому, що деяким творам притаманним стає існування тексту в тексті. Такий аспект присутній є романі Маркеса «Сто років самотності», в якому присутні завуальовані сюжети з Біблії та 3 античних міфів, які потребують уважного прочитання та окремого роз'яснення, це стосується і архетипного та алегоричного наповнення роману. Цілком логічно буде вбачати особливу мовну гру в подібній інтертекстуальності твору. Більше того, наявність такої кількості архетипів, символів, «вічних образів», створює особливу взаємодію концептуальних елементів у самому творі.

Говорячи про Біблійні тексти варто усвідомити, що ця книга сприяла формуванню i розвитку концептосфери багатьох етносів. Враховуючи наявність/відсутність фонових знань та відмінного змістового наповнення 
«культурної грамотності», ми можемо говорити, що відбувається певний внутрішній конфлікт у сприйнятті концептів, завуальованих у творі. Концепт, так само як і мова, $є$ феноменом динамічним і напевно, лише літературний твір дозволяє провести одночасну багатовимірну взаємодію концептосфер: колективної, індивідуальної авторської; індивідуальної читацької; етнокультурної загалом.

Нерідко трапляється так, що в основу літературного твору покладені певні історичні події чи факти, або ж герої творів мають реальних прототипів. У поняття «історичні події входить велика кількість соціальних елементів взаємодії, які $є$ базисом формування концепту. Автор у своєму творі може змінювати хід історичних подій, надавати їм іншого трактування або ж подавати їх таким чином, що авторський варіант ми сприйматимемо як реальність. Запорожченко Ю. у своїй статті «Имидж Германии в романе Б. Шлинка “Чтец” (Запорожченко, 2016) намагається розглянути формування іміджу Німеччини, використовуючи модель Б. Коваль. Згідно з такою моделлю імідж проходить 4 стадії:

1) вихід інформації;

2) обробка отриманої інформації;

3) зовнішні сприятливі та несприятливі чинники;

4) вплив реципієнта (читача) на поведінку оригіналу (художнього твору).

На першій стадії автор знаходить інформацію, яка слугуватиме основою для його твору або ж в якій $є$ відбиток проблеми, на яку він прагне звернути увагу читачів. На даному етапі інформація проходить крізь природний фільтр. Таким фільтром може бути або зникнення чи замовчування частини фактів, або часткове спотворення дійсної інформації, яке можна пояснити тим, що існує часовий бар'єр між первинним реципієнтом (автором) та першоджерелом.

На стадії обробки отриманої інформації автор, відповідно до власної шкали цінностей та інтенції, коригує отримані факти й представляє їх поіншому, розставляючи необхідні акценти. Б.Коваль говорить про те, що імідж(образ) має здатність типізувати, а тому подібний вторинний імідж починає сприйматись як дійсний і типовий.

Третя стадія пов'язана із впливом на створений у творі імідж зовнішнього середовища. Наприклад, ідеї та думки, висловлені у творі, можуть вступати в протиріччя 3 існуючими переконаннями та стереотипами, що притаманні читачам. Такі зіткнення відбуваються майже 3 усіма творами. Але натомість імідж(образ), що представлений у творі, 
стає самостійним і набуває можливостей впливати на переконання і світогляд читача.

Найцікавішою є четверта стадія, адже тепер імідж, презентований у творі, зазнаватиме впливу читачів, що обумовлюватиме його подальшу долю: буде він «пасивною категорією» чи все ж таки впливає на свідомість реципієнтів.

Як бачимо взаємодія між твором та читачем $є$ чимось на кшталт багатовимірного і поліфункціонального дискурсу: авторська інтенція знаходить своє відображення в іміджах, образах, проблемах, тематиці творів, тоді як читач (реципієнт) визначає важливість даного твору, його значення. Саме з читацьких оцінок ми можемо судити про досягнення чи недосягнення автором його прагматичних інтенцій у такому дискурсі. Разом з тим, думки висловлені у художньому творі можуть схиляти нас до типізації подій, розкритих у творі.

Ми спробуємо провести подібний аналіз на прикладі роману «Червоне і чорне» Стендаля:

1) Вихід інформації. Поштовхом до написання роману був процес Антуана Берте, який відбувся в грудні 1827 року. Юний Берте працював у будинку Мішу і був коханцем мадам Мішу, але його звільняють, тож він влаштовується вчителем в сім'ю аристократа. Донька нового господаря Берте закохується у вчителя і зізнається у своїх почуттях. Мадам Мішу дає аристократові погану характеристику його нового працівника i цим заважає Антуанові одружитись 3 юною мадемуазель. Аби помститись Антуан приходить у церкву і намагається застрелити мадам Мішу, а потім вчинити самогубство. Втім, і він, і вона вижили. Антуана приговорили до смертної кари і стратили (Реизов, 1977, с. 556-557).

2) Обробка отриманої інформації. Отримавши 3 цього процесу прототипів своїх героїв, Стендаль змінює інтерпретацію цієї історії: він прагне розкрити життя Франції періоду Реставрації. Письменник бажає виділити три діючі сили у французькому суспільстві: аристократію, буржуа та народ, за яким, на думку Стендаля, правда і майбутнє Франції. Мета письменника: показати як талановиту молоду людину, яка вийшла 3 «низів», приводять до трагедії і невірних вчинків замкненість соціальних класів і лицемірство та зневага до моралі.

3) Зовнішні сприятливі та несприятливі чинники. Роман «Червоне і чорне» був сприйнятий неоднозначно. Він викликав незадоволення серед духовенства, а також серед більшості знатних вельмож. Зате роман уподобали Й. Гете та О. де Бальзак. 
4) Вплив читача на поведінку оригіналу. «Червоне і чорне», як і більшість книг високої літератури, змінюють сприйняття історичного минулого. Оскільки Стендаль створював реалістичний роман, який мав віддзеркалити всю епоху, образ Жульєна Сореля ми сприймаємо як типовий. А покладена в основу роману історія та судовий процес можуть схиляти до думки, що такі бунти проти порядків були постійними й нормальними для 19 ст.

Таким чином, ми можемо спостерігати, як відбувається взаємодія між концептосферами у контексті багатовимірного дискурсу автор-читачетнос.

\section{4. Взаємозв'язок національного та авторського концептів у літературі}

Вже було зазначено, що мистецтво відіграє важливу роль у розвитку концептів, адже слугує своєрідною ланкою кросс-культурних та історичних зв'язків. М.М. Бахтін (Бахтин, 1979) вказує на те, що поруч 3 національно специфічною картиною світу має місце індивідуальна концептуальна система, а така індивідуальна картина світу $\epsilon$ досить специфічною та своєрідною. Науковець зазначає, що цілком можливими $€$ якісні відмінності інтерпретації однакових концептів та відповідних мовних виразів. Також М.М. Бахтін зазначає, що стиль письменника, митця завжди відображає домінантні настрої сучасної йому епохи, але у той же час має і свої суто індивідуальні риси.

В лінгвокультурології та літературознавстві мають місце особливі індивідуальні картини світу митців. Концепти наявні у художньому творі набувають нових барв, які часто можуть випереджати загальнонаціональні настрої та загальноприйняті трактування. Ми вбачаємо у такій концептуальній полісемії індивідуальних та загальних настроїв епохи особливий тип мовної гри.

Таким чином, якщо говорити про концепт БЕЗСМЕРТЯ (IMMORTALITY), який розглядається в дисертаційній роботі, варто зазначити, що відбуваються певні відмінності в авторському баченні його, а також у співвідношенні концепту БЕЗСМЕРТЯ з суміжними концептами ЖИТTЯ (LIFE) та CMEPTЬ (DEATH). Наприклад, Брем Стокер у романі «Дракула» створює образ вампіра, який може жити вічно, але все ж може і померти за певних обставин, що і відбувається наприкінці твору. Тоді як сучасна американська письменниця Анна Райс втілює у своїх романах про надістот зовсім інше бачення: вампіри не лише живуть вічно, але і не 
можуть померти. В ï авторському баченні концепту БЕЗСМЕРТЯ (IMMORTALITY) прослідковуються зв'язки з концептами BIЧНЕ ЖИТТЯ (ETERNAL LIFE) та МОЛОДІСТЬ (YOUNGNESS).

Суттєві зміни $є$ і в самих характерах вампірів. Персонажі-кровопивці були присутні і в староанглійських казках та легендах, але вони в них завжди поставали антагоністами, ставлення до безсмертя у тодішніх людей було негативним, БЕЗСМЕРТЯ означало належність до нечистої сили. Вампіри у романах сучасних письменників завжди перш за все люди, вони мають свої абсолютно людські почуття, слабкості, переживання, хоча i відрізняються від людини надзвичайною фізичною витривалістю, необхідністю пити людську кров та надможливостями (невидимістю, швидкістю, надзвичайно гучним голосом тощо).

Варто зазначити, що в україномовних творах істоти наділені безсмертям мешкають поодаль від людей, зрідка контактуючи зі смертними, тоді як Анна Райс створює у романі «Вампір Лестат» образ вампіра, який не лише не старається уникати людей, але й стає відомим рок-музикантом.

Як бачимо, Анна Райс створює образ містичної істоти, який $\epsilon$ максимально наближеним до людського. Окремою складовою авторського бачення БЕЗСМЕРТЯ у Анни Райс $\epsilon$ і те, що саме Лестат $\epsilon$ iii улюбленцем і за словами письменниці, їй простіше лишити роман незакінченим, аніж допустити думку, що створений нею персонаж помре за сюжетом. I неможливо не пригадати паралель, між концептами БЕЗСМЕРТЯ і МИСТЕЦТВО(ART), яку проводить письменниця у романі: вампір Маріус постійно з'являється на портретах відомих художників, Лестат віртуозно грає на скрипці.

Концепт БЕЗСМЕРТЯ у контексті «безсмертя людини» все ж не може бути сприйнятий у повній мірі, адже поки що ніхто не досягнув того, що даний концепт втілює. Тим не менш, саме американські та австралійські вчені Керол Грейдер та Елізабет Блекберн, а також Джек Шостак в 2009 році отримали Нобелівську премію за відкриття ферменту теломерази, активація якого може зупинити старіння організму, а відтак і давати надію на можливість вічного життя. Певною мірою настрої та світобачення художників та науковців переплітаються, даючи змогу говорити про можливий вплив авторського концепту на світосприйняття націй та етносів.

В даному розділі було здійснено спробу застосувати теоретичні напрацювання Л.Вігенштейна у комплексі 3 літературознавчими та 
лінгвістичними прийомами та методами аналізу для розгляду концептів та їх елементів у літературних творах:

\section{4. Висновки та перспективи}

Поставивши за мету даної роботи визначити специфіку формування уявлення про концепт у філософії Людвіга Вітгенштейна та дослідити особливості функціонування концептів у літературних творах.

Результати досліджень дозволяють стверджувати, що Л.Вітгенштейн спершу намагався звести природну мову до повідомлення фактів 3 використанням атомарних, та молекулярних речень, яку називав «ідеальною мовою науки», і описав модель їі функціонування у «Логікофілософському трактаті». Але вона $є$ вкрай недосконалою і не дозволяє передати усієї полісемії слова, а також - не дозволяє використовувати її у вирішенні питань етики, естетики та метафізики. Чітке розуміння терміну «концепт» філософ подав у праці «Філософських дослідженнях». Філософ відмовився від попередніх поглядів і взявся за вивчення парадигми змін слова, та його полісемії. Саме такий розгляд значення слова підводить науковця до розгляду концепту та системи концептів концептосфери.

На думку Вітгенштейна, спочатку концепт являє собою симбіоз чуттєвого досвіду та ключових для людини характеристик предмету, який трансформується у базове уявлення про об’єкт суб'єктивної дійсності ядро концепту. Після цього на базове уявлення нашаровуються нові смисли, це відбувається у процесі зміни поколінь, при різних соціальних та культурних взаємодіях. «Мовні ігри» та «ігри поведінки» - $є$ особливими способами репрезентації парадигмальних змін значення слова та розкриття полісемії значень концепта.

Розглядаючи роботи сучасних науковців - лінгвістів, культурологів, літературознавців - А. Огар, О.Селіванової, І. Голубовської, М. Манакіна ми можемо зробити висновок, сьогодні існує багато визначень концепту, деякі з них розглядають концепт як частину мовної картини світі, інші - як частину концептуальної картини світу. Але найбільш точним ми вважаємо модель, запропоновану О.Селівановою, оскільки в ній подібно до моделі Вітгенштейна $є$ ядро та периферійні нашарування значень, така модель дозволяє стверджувати, що концепт $є$ ментальним утворенням в динаміці розвитку і змін. 
Враховуючи запропоновану Л.Вітгенштейном модель концепту, а також його визначення ним соціальної взаємодії як рушійної сили у формуванні концепту, було здійснено спробу застосувати теоретичні напрацювання Л.Вігенштейна у комплексі 3 літературознавчими та лінгвістичними прийомами та методами аналізу для розгляду концептів та ïх елементів у літературних творах: було здійснено спробу розглядати його теоретичні та практичні напрацювання при дослідженні концептів у літературних творах.

Ми розглянули концепт як імпліцитний елемент інокультури на прикладі повісті Я. Кавабати «Тисяча журавлів». Клименко Ж.В., виділяє національно-культурні символи, національні еталони i стереотипи, національно-прецедентні феномени та фрейм-структури свідомості. Ми вважаємо, що такі елементи можуть бути розглянуті як елементи концептосфери окремого етносу/нації.

«Природна мова» завдяки своїй динамічності смислів та «пластичності» дозволяє спрощувати розуміння інокультурних текстів, подаючи роз'яснення безеквівалентних лексичних одиниць.

Встановлено зв'язок між поняттям «мовна гра» Л.Вітгенштейна та поняттями «фонові знання» Сафаряна С.I. та «культурна грамотність» Е.Хірша-молодшого: фонові знання та культурна грамотність допомагають зорієнтуватись у культурно-історичному просторі та створити «зачіпки» в людській свідомості, які міститимуть уявлення про ту чи іншу культуру або історико-культурну епоху, дозволяючи простежувати динаміку розвитку концептів зокрема та культури загалом.

Використовуючи модель аналізу зміни іміджу країни/подій/епохи Ю.Запорожченка, ми спромоглись провести паралель між іміджем та концептом, оскільки імідж розглядався нами як елемент концептосфери. Таким чином ми прослідковуємо багатовимірні варіанти взаємодії між автором і читачем, можливості авторської зміни картини реальності у літературному творі, які іноді навіть можуть змінювати світосприйняття читачів.

На прикладі роману «Вампір Лестат» Анни Райс ми розглянули зміну усталеного загальноприйнятого концепту БЕЗСМЕРТЯ в концепт авторський: обмеженість безсмертя і розгляд безсмертя як вияву концепту ЗЛА, письменниця змінює на концепт БЕЗСМЕРТЯ, що граничить 3 концептами ЛЮДИНА і МОЛОДІСТЬ, а також проводить у творах своєрідну паралель з концептом МИСТЕЦТВО.

Модель концепту, яку запропонував Людвіг Вітгенштейн у «Філософських дослідженнях» ми вважаємо досконалою та вбачаємо 
можливість застосування ії при розгляді втілення концептів у художніх літературних творах.

\section{Бібліографія}

Бахтин, М.М. (1979). Вопросы литературы и эстетики. М., Искусство. 306с.

Бахтин, М.М. (1979). Эстетика словесного творчества. М.: Искусство. 424 с.

Бацевич, Ф.С. (2004). Основи комунікативної лінгвістики. К.: Академія. 343 с.

Голубовская, И.А. (2002). Этнические особенности языкових картин мира. Издательскополиграфический центр “Киевский университет”. 293 с.

Жайворонок, В.В. (2006). Знаки української етнокультури : словникдовідник. К.: Довіра. $703 \mathrm{c}$.

Запорожченко, Ю. (2016). Имидж Германии в романе Б. Шлинка «Чтец». Південний архів. Збірник наукових праць. Філологічні науки. 48-53 с. [Електронний ресурс]

Режим доступу:

https://www.google.com/url?sa=t\&rct=j\&q=\&esrc=s\&source=web\&cd=\&cad=rja\&uact=8\& ved=2ahUKEwiWkLyZjOfsAhVuw4sKHfvKBY0QFjABegQIAhAC\&url=https\%3A\%2F\% 2Fs.siteapi.org\%2F502de94e2971eb6\%2Fdocs\%2F9aca0c601b5c1fb23094da19b89719b085 32990a.pdf\&usg=AOvVaw1WkUpKiIXZCxtQrDKnGNDh

Клименко, Ж.В. (2006). Етнокультурологічний шлях аналізу як ефективний засіб осягнення національної специфіки твору. Всесвітня література в середніх навчальних закладах України. №5. С. 13-17.

Клименко, Ж.В. (2006) Теорія і технологія вивчення перекладних художніх творів у старших класах загальноосвітньої школи: Монографія. К. 340 с.

Клименко, Ж.В. (2000). Формування уявлення учнів про загальнолюдське та національне в літературі. Зарубіжна література в навчальних закладах. №5. С. 5-8.

Витгенштейн. Л. (2005). Избранные работы. Пер. с нем. и англ. В. Руднева. М.: Издательский дом «Территория будущего». с. 440.

Манакін, В.М. (2012). Мова і міжкультурна комунікація. Київ: ЦУЛ. 288 с.

Огар, А. (2013). Суперечливі аспекти поняття "концепт". Проблеми гуманітарних наук. Філологія. Вип. 32. С. 242-252.

Реизов, Б. (1977). Красное и черное [післямова]. Стендаль. Красное и черное. М.: Художественная литература. с. 556-560.

Сафарян, С.I. (2002). Виокремлення фонових знань: засади, прийоми. Всесвітня література в середніх навчальних закладах України. №1. С. 50-53.

Сафарян, С.I. (2003). Фонові знання - база, що забезпечує поглиблене прочитання твору. Всесвітня література в середніх навчальних закладах України. №3. С. 43-44.

Селіванова О.О. (2012) Світ свідомості в мові. Мир сознания в языке: [монографічне видання]. Черкаси: Ю. Чабаненко. 488 с.

Словник літературознавчих термінів. [Електронний ресурс]. Режим доступу: http://www.ukrlit.vn.ua/info/dict/

Сокулер, 3. А. (1994) Людвиг Витгенштейн и его место в философии ХХ века.: Курс Лекций. Долгопрудный Аллегро-Пресс. 173 с.

Токмань, Г. Л. (2012) Методика викладання української літератури. Підручник. К.: Академія. 312 с. 
Чижова, Л.А. (2007) Понятие концепта и системы концептов в теории коммуникации. M. 134 c.

Черкезова, М. В. (1981) Русская литература в национальной школе: Принцип общности и национального своеобразия литератур народов СССР в процессе преподавания русской литературыг. М.: Педагогика. 152 с.

Borchert, D.M. (2006) Encyclopedia of Philosophy. Thomson Gale. T. 7. C. 325 p.

Honderich, T. (ed.) (2005). The Oxford companion to philosophy. New York: Oxford University Press. 1060 c.

Kaufer, D. S. Cultural Literacy: A Critique of Hirsch and an Alternative Theory. [Електронний ресурс]. Режим доступу: http://web.archive.org/web/20050506190807/http://www.mla.org/ade/bulletin/N094/0940 23.htm

Wierzbicka, A. (1997). Understanding Cultures Through Their Key Words: English, Russian, Polish, German, and Japanese. Oxford University Press - Social Science. 317 p.

\section{REFERENCES}

Bakhtyn, M.M. (1979). Voprosy literatury ta estetyky. - M., Iskusstvo. 306s.

Bakhtyn, M.M. (1979). Éstetyka slovesnoho tvorchestva. M.: Iskusstvo. 424 s.

Batsevych, F.S. (2004). Osnovy komunikatsiyi diyal'nosti linhvistyky. K.: Akademiya. 343 s.

Holubovskaya, Y.A. (2002). Etnichni osoblyvosti movnykh kartyn svitu. K.: Izdatel's'kopolihrafichnyy tsentr «Kyyivs'kyy universytet». $293 \mathrm{~s}$.

Zhayvoronok, V.V. (2006). Znaky ukrayins'koho etnokul'tury: slovnykdovidnyk. K.: Dovira. $703 \mathrm{s.}$

Zaporozhchenko, YU. (2016). Ymydzh Hermanyy v romane B. Shlinka «Chtets'». Pivdennyy arkhiv. Zbirnyk naukovykh prats'. Filolohichni nauky. 48-53 c, [Elektronnyy resurs]

Rezhym dostupu: https:/www.google.com/url?sa=t\&rct=j\&q=\&esrc=s\&source=web\&cd=\&cad=rja\&uact=8\& ved=2ahUKEwiWkLyZjOfsAhVuw4sKHfvKBY0QFjABegQIAhAC\&url=https\%3A\%2F\% 2Fs.siteapi.org\%2F502de94e2971eb6\%2Fdocs\%2F9aca0c601b5c1fb23094da19b89719b085 32990a.pdf\&usg=AOvVaw1WkUpKiIXZCxtQrDKnGNDh

Klymenko, ZH.V. (2006). Etnokul'turolohichnyy shlyakh dosyahnuto yak efektyvnishyy instrument vyroblennya natsional'nykh spetsial'nykh tvoriv. Vsesvitnya literatura v serednikh navchal'nykh navchal'nykh zakladakh Ukrayiny. №5. S. 13-17.

Klymenko, ZH.V. (2006). Teoriya ta tekhnolohiyi perekladu khudozhnikh tvoriv u starshykh klasakh zahal'noosvitn'oyi shkoly: Monohrafiya. K. 340 s.

Klymenko, ZH.V. (2000). Formuvannya vtilennya u navchanni pro zahal'nolyuds'ke ta natsional'ne v literature. Zarubizhna literatura v navchal'nykh zakladakh. №5. S. 5-8.

Vithenshteyn, L. (2005). Yzbrannye raboty Per. z nim. i anhl. V. Rudneva. M.: Yzdatel'skyy dom «Terrytoriya maybutn'oho». s. 440.

Manakin, V.M. (2012). Mova i mizhkul $\square$ turna komunikatsiya. Kyyiv: TSUL. 288 s.

Ohar, A. (2013). Superechlivi aspekty ponyattya "kontsept". Problemy humanitarnykh nauk. Filolohiya. Vyp. 32. S. 242-252.

Reizov, B. (1977). Krasnoe i chorne [pislyamova]. Stendal'. Krasnoe i chorne. M.: Khudozhestvennaya literatura. s. 556-560. 
Safaryan, S.I. (2002). Vyokremlennya fonovykh znan': zasady, pryyomy. Vsesvitnya literatura v serednikh navchal'nykh zakladakh Ukrayiny. №1. S. 50-53.

Safaryan, S.I. (2003). Fonovi vidomosti - baza, yaka pohlyblyuye problemu tvorinnya. Vsesvitnya literatura v serednikh navchal'nykh zakladakh Ukrayiny. №3. S. 43-44.

Selivanova, O.O. (2012). Svit svidomosti v movi. Mir soznaniya na movi. Cherkasy: YU. Chabanenko. $488 \mathrm{~s}$.

Slovnyk literaturoznavchykh terminiv. [Elektronnyy resurs]. Rezhym dostupu: http://www.ukrlit.vn.ua/info/dict/

Sokuler, Z. A. (1994). Lyudvyh Vithenshteyn i yoho mistse u filosofiyi XX veka: Kurs Lektsiy. Dolhoprudnyy Allehro-Press. $173 \mathrm{~s}$.

Tokman', H. L. (2012). Metodyka vyboru ukrayins'koyi literatury. Pidruchnyk. K.: Akademiya. $312 \mathrm{~s}$.

Chyzhova, L.A. (2007). Ponyattya kontseptsiyi ta systemy kontseptsiy v teoriyi komunikatsiyi. M. $134 \mathrm{~s}$

Cherkezova, M. V. (1981). Rus'ka literatura v natsional'niy shkoli: Pryntsyps'ka spil'nist' i natsional'ne svoyeobrazye literaturnykh narodiv SRSR $\mathrm{v}$ protsesi peredbachennya rosiys'koyi literatury. M.: Pedahohika. $152 \mathrm{s.}$

Borchert, D. M. (2006). Encyclopedia of Philosophy. Thomson \& Gale. T. 7. C. 325 p.

Honderich, T. (ed.) (2005). The Oxford companion to philosophy. New York: Oxford University Press. 1060 c.

Kaufer, D.S. Cultural Literacy: A Critique of Hirsch and an Alternative Theory. [Електронний ресурс] Режим доступу: http://web.archive.org/web/20050506190807/http://www.mla.org/ade/bulletin/N094/0940 23.htm

Wierzbicka, A. (1997). Understanding Cultures Through Their Key Words: English, Russian, Polish, German, and Japanese. Oxford University Press - Social Science. 317 p. 
